\title{
Survey of the Factors Affecting Women's Income in IFAD Poverty Alleviation Project in Cambodia
}

\author{
HaoYin \\ International Business School \\ Yunnan University of Finance and Economics \\ Kunming, China \\ yinhaoli@163.com \\ Vanny Peou \\ Department of International Cooperation
}

\author{
Ministry of Agriculture Forestry and Fisheries \\ Phnom Penh, Cambodia \\ peouvanny@rocketmail.com
}

\author{
Huiping Liu* \\ International Business School \\ Yunnan University of Finance and Economics \\ Kunming, China \\ hp953364780@126.com
}

\begin{abstract}
Cambodia is a country which with a vast territory but along with a sparse population, its residents should benefit from this. But on the contrary, the reality is that most people in Cambodia still live on the edge of poverty, which is partly due to the low income of women. Female labor accounts for a large proportion of rural areas in Cambodia, but their efforts are usually not recognized, which leads to lower incomes of women. This survey made poverty alleviation project in Prey Veng province as a case, analyzed the factors impact female income in Cambodia. According to the survey, there are two key factors that affect women's income levels, education and family size.
\end{abstract}

Keywords-women's income; poverty alleviation projects; cambodia

\section{INTRODUCTION}

Cambodia is a very rich natural resources country that could definitely provide for everyone who living in. The country has the advantage of a small people (14milions with $181.035 \mathrm{~km}^{2}$ ) which should introduce high resources for everybody, while compared to Thailand or Vietnam especially which have about $90 \mathrm{~m}$ populations in similar land area. However, in Cambodia, there is a remarkable weakness, the subsistence of a large part of its population highly dependent on agriculture sector. The biggest shortage is that food stability is easily interrupted by shocks, such as illness in the family, price fluctuations and natural disasters. And that's why a quantity of Cambodian living under or just above the poverty line. Urgent attention must be attached to the poverty issue, especially rural poverty, in Cambodia.

Cambodia has a wide rural population and trusts on the agriculture sector for engagement, exports, economic growing, and food safety. It is an important source of occupation for women and is also significant in rural areas for poverty reduction.

In term of world growing economic, the role of women to introduce their importance to improve livelihood as well as small families and the development of Cambodia country. As a key role in the agriculture sector, Cambodian women has presented that, they occupy 56 per cent of the survival farmers and 54 per cent of the labors in the agriculture sector on market concerned with. However, their labor involvement frequently unappreciated and mostly work as unpaid family labors. Access to extension services, credits and markets survive limited for most Cambodian citizens, but female's farmers tend to be more marginalized than men due to their limited flexibility and time, as well as their rejection from male influence community networks. For the poor people in Cambodia, food insecurity has been a serious problem, and 90 per cent of them are living in rural areas. This problem is especially serious for rural women who are responsible for 80 per cent of food production.

The most important problem is that women farmers have unequal opportunity to obtain land or register it in their own names. They could also have fewer legacy rights than male farmers. Land proprietorship is important not only to women's capability to earn income but also as a source of empowerment and independence within the household. Their ability to earn access to credit facilities is affected by lack of land, too.

In order to improve the income of women and reduce poverty, the poverty alleviation project carried out in Prey veng province, Cambodia, was selected to be studied. This project started from 2003-2013 and focused on rural poverty reduction, and is supported by International Fund for Agriculture Development (IFAD) with technical and financial. And the objective is to promote the role of women in economic development, to provide an assessment of the use of available natural resources and to do small businesses, targeting groups such as less land, population without land, the local population, people and women-headed households, mainly children and / or families dependent on relatives.

\section{LITERATURE REVIEW}

In all developing regions, women create important sharing to the agricultural and rural economies. Although their roles

* Corresponding author 
differ much among and in side countries and are varying quickly in several parts of the world, it is undeniable that their power is changing the status of agriculture and services. Frequently, rural women manage multifaceted families and follow many livelihood strategies. Their performance typically contain tending animals, making agricultural products, cooking food, engaging in trade and marketing, occupy in farming or other rural enterprises, collecting fuel and water, maintaining their homes and caring for family members. Many of these performances have not defined as "economically active employment" in national accounts, but they are essential to the well-being of rural households. In lots of developing countries, the agricultural sector is failing in sharing of women, who represent a key resource in agriculture and the rural economy over workers and businesspersons, women role as agriculturalists, but they face more serious constraints than men in entree to prolific resources, practically in all places. National governments and the international community efforts made changing or to reach their objectives for economic growth, agricultural improvement, and food safety will be reinforced and speeded, if they build on the contributions that women feel free or independent to relieve these constraints.

The Global Development Community has realized that, in regions where it is the essential livelihood of the poor, agriculture is the key role of growing and poverty reduction. Globally, one fourth of all women were involved in agriculture, in 2015. Even though occupation women in this sector have declined over the last twenty years, agriculture remains the most significant source of employment for women in lower middle income and low-income countries. Meanwhile, women create important sharing in all developing regions to the agricultural and rural economies. However, the lack of rights of women have effect to resource distribution and making decisions in family, community and public, where men are expected to express for the whole family.

Gender disparities showed that living conditions of poor men was very much higher than poor women. It is also appearance that women are affected more sternly by poverty than men. An investigation of the 20-year period from 1970 to 1990 shows that the amount of rural women living in unqualified poverty has increased by 50 percent, compared to a 30 percent increase among men [5].

Astrid Ruiz Thierry (2007) pointed out, that the main objective of several gender mainstream efforts is to make it more gender-friendly in changing the status quo, so that women are able to gain the right of competing fairly with men [4].

The agricultural sector shared around $31.6 \%$ of GDP in 2013, also, $24.1 \%$ has shared by industry and $38.5 \%$ has shared by services, in Cambodia. However, what is noteworthy is that the influence of agricultural sector reduced from $33.9 \%$ to $31.6 \%$ in $2010-2013$ as the industrial sectors, service and construction have been developed after the end of the global economic crisis. The instability of the part of agricultural sector in the GDP depends on the other two significant economic development sectors, construction industry, and services.

In order to cope with the continued increase in costs, price fluctuations and natural disasters, and to ensure that farmers' income continues to grow, Cambodian agriculture is moving towards new value added, productive and competitive agriculture in long-term vision. For many Cambodian farmers, their lives have changed, benefiting from higher-yielding crops and higher agricultural prices. The Ministry of Agriculture said that in the past period of time, the income of the farm has increased, and could be better linked to the wages of other sectors [6].

Women's contribution in the employment in Cambodia is high, but compare to about $59 \%$ of men, $70 \%$ of employed women are in vulnerable engagement. Though women own $65 \%$ of all trades in Cambodia, the most popular of women's trades are microenterprises: $51 \%$ employ only one person, and $96 \%$ occupy four or less persons. Evidence of high undernourishment and anemia between women and a high occurrence of domestic ferocity indicate women's mediocre position and disadvantaged access to resources [2]

Related to human resource management in rural of Cambodia, the research had found that the management had not include information about women participation in management at any level, from provincial governor to lowest level as on organizational structure.

Cambodian authorities and predictors emphasized that the role played by women in agricultural sector is very important, especially as the nation's economic circumstances continue to force many men to pursue work abroad. Some 75 percent of Cambodia's women are worked in agriculture [7].

According to the results of the Cambodia Inter-Censal Population Survey (CIPS) 2013, in Cambodia, for employed female population nationally, $52.8 \%$ of them were between 15 and 65 years old, and an even larger sharing in rural areas, $65.2 \%$ worked in the primary sector; at labors aged 15 years and older, $62.1 \%$ of all men's engagement and $66.3 \%$ of all women's occupation is in agriculture. In a context of low social safety facility, agriculture is a significant form of livelihood for older population [1].

For refining rural women's conditions in year 2015, the Cambodian government built strategies implanting gender in the agricultural sector, with the purpose of improving the conditions of women in rural areas, as well as forceful more women to involve in the sector.

The institutes to provision women's economic empowerment include gender working groups and the Ministry of Women's Affairs (MOWA), in each line ministry that prepare and implement gender mainstreaming action strategies or plans. For considering priorities of plan, it was noted that three areas of intervention should be included:

(i) Provided educating or short training to gender group for women those whose occupations are reliable in labor market.

(ii) Capacity safeguarding, women can lead and raise their enterprises in any size, and be able to changing from the informal to the formal sector.

(iii) Livelihoods educating in rural areas, particularly for poor women [3]. 
Also found from the literature review, the agricultural sector in Cambodia had improved, but still did not mention the contribution of women in poverty reduction, although the majority of workers in the agricultural sector were women.

\section{DAta Collection}

In order to get some information about farmers' annul income, a questionnaire was carried out. Three stage stratified random sampling method was used to select the samples.

Firstly, process document to get permission from ministry of agriculture, forestry and fisheries (MAFF), work with Prey Veng province managers such as provincial department of agriculture (PDA) and district office of agriculture (DOA);

Secondly, discussion with the district agriculture manager, agriculture production and other living base in project IFAD period until now was identified as strata.

Thirdly, discussion with the related agencies of the townships within district, first stage is random selection of villages within the selected interviewee within the townships. Then, second stage is random selection of farmers within the villages. Through the discussion with the village head committee cooperating with officers of the township agriculture office, by the arrangement of the committee, 140 samples were collected by using interview in the study area.

The questionnaire is divided into 5 parts, namely:

(1) General Information: the description of location and project total.

(2) Interviewee's Information: include genders, ages, Current marital status, education and annual income.

(3) Family's Information: include family's member, land belonging, crops planting, the strengths and weaknesses of Farmer Field School course, the most important constraint in their participation on poverty reduction, the suggestion in order to improve their participation in poverty reduction and extension information by radios, Newspapers and televisions.

(4) The importance of women: the participation of female number of the family in Rural Poverty Reduction Project (RPRP) in qualitative data, by evaluate interviewee's feeling with 16 questions as the detail is in the appendix as well.

(5) The family change due to the project: include the result after the project which presented their approximate annual income, annual expends, Health, Jobs, education and society involving.

\section{SAMPLES AND DATA ANALYSIS}

\section{A. Sample Descriptions}

After discussion with district manager, township managers, farmers group and representatives from village head committee, Prey Veng province was selected as the case to analysis, which includes Kampong Trabaek District, commune of Kou Khchak and 4 villages (Chom Rest 35 families, Prey Thom 31 families, Prey Snoul 37 families and Kou Khchak families).

From IFAD project target with 600 people, sample of 140 people were selected, it meant to select 140 out of 600 .

Now it introduces how much percentage was get, it was using the formula of:

Sampling fraction $=$ Actual sample size $/$ Total population, $=140 / 600=0.233=23 \%$.

Then even it can compute how numerous of people signify each one of the basics of the sample. It makes the other proportion, now split the figure of elements of the people by the number of elements of the sample: $600 / 140=4$, which would mean that each of the people of the sample represents 4 interviewees of the IFAD project target people.

\section{B. The key factors that affect women's income in Cambodia}

\section{1) Data Consolidation (See TABLE I )}

In order to identify the main factors affecting women's income, the three key indicators were selected, namely, gender, education, and family size, these three indicators were divided into different grades:

Gender was divided to male and female undoubtedly. Education was divided into 4 grade, illiteracy (cannot read or write), primary school, secondary school, and high school. For family size, it was divided to family members are less than 4 and between 4 and 11 .

TABle I Analysis Of Gender, EducAtion , FAmily Size, And Income

\begin{tabular}{|c|c|c|c|c|c|}
\hline \multicolumn{3}{|c|}{ Group 1: Farm. Gender = female(81 families) } & \multicolumn{3}{|c|}{ Group 2: Farm. Gender = male(59 families) } \\
\hline Farm. Edu. & Farm. family & Average farm. income (KHR) & Farm. Edu. & Farm. family & Average farm. income (KHR) \\
\hline \multirow{2}{*}{$\begin{array}{c}\text { Group } 1.1 \\
\text { Cannot read or write } \\
36 \text { families }\end{array}$} & $\begin{array}{l}\text { Group 1.1.1 } \\
14 \text { families }\end{array}$ & $1,300,000$ & \multirow{2}{*}{$\begin{array}{c}\text { Group } 2.1 \\
\text { Cannot read or write } \\
12 \text { families }\end{array}$} & $\begin{array}{c}\text { Group 2.1.1 } \\
4 \text { families }\end{array}$ & $1,500,000$ \\
\hline & $\begin{array}{l}\text { Group } 1.1 .2 \\
22 \text { families }\end{array}$ & $1,180,000$ & & $\begin{array}{c}\text { Group } 2.1 .2 \\
8 \text { families }\end{array}$ & $1,300,000$ \\
\hline \multicolumn{3}{|c|}{ TOTAL Group 1.1} & \multicolumn{3}{|c|}{ TOTAL Group 2.1} \\
\hline \multirow{2}{*}{$\begin{array}{l}\text { Group } 1.2 \\
\text { Primary school } \\
43 \text { families }\end{array}$} & $\begin{array}{l}\text { Group } 1.2 .1 \\
16 \text { families }\end{array}$ & $1,250,000$ & \multirow{2}{*}{$\begin{array}{c}\text { Group } 2.2 \\
\text { Primary school } \\
33 \text { families }\end{array}$} & $\begin{array}{l}\text { Group } 2.2 .1 \\
18 \text { families }\end{array}$ & $1,400,000$ \\
\hline & $\begin{array}{c}\text { Group 1.2.2 } \\
27 \text { families }\end{array}$ & $1,500,000$ & & $\begin{array}{c}\text { Group } 2.2 .2 \\
15 \text { families }\end{array}$ & $1,300,000$ \\
\hline \multicolumn{3}{|c|}{ TOTAL Group 1.2} & \multicolumn{3}{|c|}{ TOTAL Group 2.2} \\
\hline \multirow{2}{*}{$\begin{array}{c}\text { Group } 1.3 \\
\text { Secondary school } \\
0 \text { family }\end{array}$} & $\begin{array}{c}\text { Group } 1.3 .1 \\
0 \text { family }\end{array}$ & 0 & \multirow{2}{*}{$\begin{array}{c}\text { Group } 2.3 \\
\text { Secondary school } \\
14 \text { families }\end{array}$} & $\begin{array}{c}\text { Group } 2.3 .1 \\
5 \text { families }\end{array}$ & $1,300,000$ \\
\hline & $\begin{array}{c}\text { Group } 1.3 .2 \\
0 \text { family }\end{array}$ & 0 & & $\begin{array}{l}\text { Group } 2.3 .2 \\
9 \text { families }\end{array}$ & $1,600,000$ \\
\hline \multicolumn{3}{|c|}{ TOTAL Group 1.3} & \multicolumn{3}{|c|}{ TOTAL Group 2.3} \\
\hline
\end{tabular}




\begin{tabular}{|c|c|c|c|c|c|}
\hline \multirow{2}{*}{$\begin{array}{l}\text { Group } 1.4 \\
\text { High school } \\
2 \text { families }\end{array}$} & $\begin{array}{c}\text { Group } 1.4 .1 \\
2 \text { families }\end{array}$ & $2,500,000$ & \multirow{2}{*}{$\begin{array}{c}\text { Group } 2.4 \\
\text { High school } \\
0 \text { family }\end{array}$} & $\begin{array}{c}\text { Group } 2.4 .1 \\
0 \text { family }\end{array}$ & 0 \\
\hline & $\begin{array}{c}\text { Group } 1.4 .2 \\
0 \text { family }\end{array}$ & 0 & & $\begin{array}{c}\text { Group } 2.4 .2 \\
0 \text { family }\end{array}$ & 0 \\
\hline \multicolumn{3}{|c|}{ TOTAL Group 1.4} & \multicolumn{3}{|c|}{ TOTAL Group 2.4} \\
\hline
\end{tabular}

Notes: Group a.b.1: $\quad 0 \leqslant$ family member $\leqslant 4 ; \quad$ Group a.b. $2 ; \quad 5 \leqslant$ family member $\leqslant 11(a=1,2 ; b=1,2,3,4)$

$1 \mathrm{USD}=4050 \mathrm{KHR}$, the exchange rate at July 1th, 2016; KHR=Cambodian Riel

\section{2) Data Analysis} income

a) Analysis of the relationship between gender and

By comparing group 1 and 2 , it could be found that the average income of women is greater than that of men, women $=1,546,000$ Riel $>$ males $=14$ million Riel. And this result shows that women play a more important role in poverty reduction, strengthening the education and support of women and improving the average living standard of women will contribute to the effective development of poverty alleviation work. Therefore, national governments and institutions of poverty alleviation should focus on women in their daily work, improve women's survival and work skills through various means, thereby increasing women's income and reducing the national poverty rate. income

b) Analysis of the relationship between education and

In order to find the relationship between education and family income, the income gap between Group 1 and 2 at the same level of education should be measured (See TABLE II ). Then it could be found that:

TABLE II Income Gap Between Female (Group 1) And Male (Group 2) AT THE SAME LEVEL OF EDUCATION

\begin{tabular}{|c|r|}
\hline Groups & Income gap (KHR) \\
\hline (Group1.1)-(Group2.1) & $-140,000$ \\
\hline (Group1.2)-(Group2.2) & $+52,000$ \\
\hline (Group1.3)-(Group2.3) & $-1,493,000$ \\
\hline (Group1.4)-(Group2.4) & $+2,500,000$ \\
\hline
\end{tabular}

In the case of education, the income of lower-educated female households is lower than that of men, but women with higher education receive more income than men. This may be because those educated women with larger family members may have higher management skills. This shows that under the same level of education and family size, women are born with higher management skills than men, which may be due to women's mind more delicate, but also know how to coordinate interpersonal relationships, make full use of personal expertise and other factors. Therefore, to improve the level of female education, provide job skills training women, will improve the female income and the national average income effectively, and reduce poverty.

c) Analysis of the impact of education and family size on women's income

(1) Comparing female income those who have same education but different family size (see Fig 1), it was fairly obvious that:

In lower education, the income of small family members is higher than that of large families, but contrary to higher education. This is partly due to that women with low levels of education can only engage in high-input but low-output jobs, such as agricultural production. In this case, the larger family size means that limited household income needs to be given for more people, which will lead to a reduction in the average household income level. In the high level of education, women can engage in low-income but high-output or high-input and high-output jobs, such as government work, foreign trade, etc. At this time, the larger family size means that more members of the family can engage in high-income jobs, which led to a higher average household income. Another explanation is that under the high educational level, the average household income is not sensitive to changes of family size, namely, the size of the family has little effect on the average household income, due to the proportion of family members engaged in high-income jobs. Therefore, to implement the family planning policy in rural areas of Cambodia and reduce the rural population will be helpful to improve the living standards and reduce the poverty rate in Cambodian rural areas.

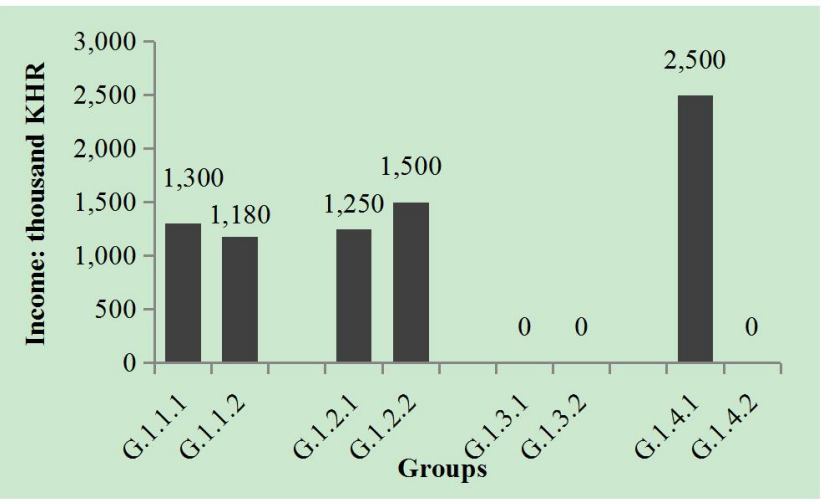

Fig 1 The Effect of Family Size on Income

(2) Comparing female income those who have same family member but different education (see Fig 2), it shows that:

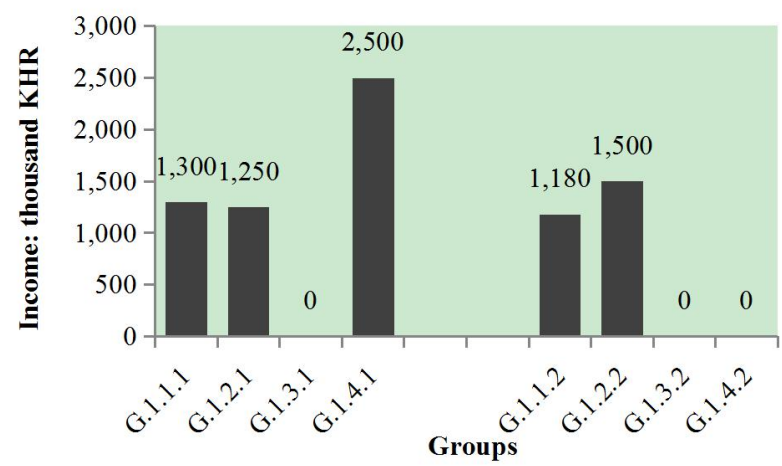

Fig 2 The Effect of Education on Income

In both small families and large families, women with higher education have a higher income, in other words, income 
is proportional to education. Therefore, to implement the adolescent compulsory education, improve the level of education of women, provide skills training for those women who have been on working, will help improve the national average income level and reduce poverty.

(3) Controlling the impact of education and family members, it shows that:

Female in low educated with small families got smaller income than male, but with larger families female got similar income to male. The more interesting phenomenon is that female in high educated with small families got similar income to male, but in large families female got higher income than male. This may be due to the fact that female leaders are usually not convinced, so women always need more management skill to coordinate the family members than man, then it is characterized by higher income when the management skill is applied to work. It means that educated women with higher management skills can improve their living standards much more quickly than man.

\section{CONCLUSIONS}

The poverty situation in Cambodia is not immutable, and its poverty rate has steadily declined from 53 per cent to around 21 per cent between 2007 and 2011, including the 2008 and 2009 world financial crises. Cambodian women suffer unequal treatment without much change, and still include agricultural landowners, education, decision-making, labor, wages, time and job overload, and gender discrimination.

With the latest poverty reduction data in the world, it was conducted that a critical study of IFAD projects and is more evident and available in rural areas of Cambodia. The current study found that $58 \%$ of women actively participate in IFAD projects, more encouragement and support from authorities and other relevant partners is demanded, and more than 100 families lack technical, most of the peasant spending is much higher than income, and women are willing to be educated. Higher levels in the extended family, the lower education of women with higher management skills than women with lower education, and health-related women, most women are easier to sick than men, basic education lower than men, women are lower to assess jobs.

Based on what was found from the survey, it could be helpful to increase women's income and reduce poverty, to suggest Cambodian government to consider encouraging more and more women to participate in agriculture and rural areas, providing technical training (long-running and short-term), providing basic education, especially women and girls, so that they can read and write at least, study domestic and foreign tourism, provide basic funds, medical insurance.

\section{ACKNOWLEDGMENT}

We would like to express our sincere gratitude to His Excellency Veng Sokhon, Minister of Agriculture Forestry and Fisheries of Cambodia, for supporting us in research with collection data at Prey Veng province. We also want to thanks the anonymous reviewers for their comments.

\section{REFERENCES}

[1] ADB, "Gender equality in the labor market in Cambodia," 6 ADB Avenue, Mandaluyong City 1550 Metro Manila, Philippines, 2013, pp. 31-34.

[2] ADB, "Cambodia Country Poverty Analysis 2014, 6 ADB Avenue," Mandaluyong City 1550 Metro Manila, Philippines, 2014, pp. 11-14.

[3] ADB, "Promoting women's economic empowerment, 6 ADB Avenue," Mandaluyong City, 1550 Metro Manila, Philippines, 2015, pp. X-33.

[4] R.T. Astrid, "The elephant in the room: gender and export-led poverty reduction," Management Decision, vol. 45, 2007, pp. 1359-1376.

[5] IFAD, Rural poverty in Cambodia, Via del Serafico, 107-00142 Rome, pp. 1-6, October 2007.

[6] Ministry of Planning, "Economic Census of Cambodia 2011 Provincial Report 14 Prey Veng Province, RGC; Supported by: Government of Japan and Japan International Cooperation Agency (JICA), 2013, pp. I-1.

[7] World Bank, Cambodia EAP, pp. 1-2, April 2015. 